\title{
MIGRACJE ZAGRANICZNE DO POLSKI A PROBLEM BEZPIECZEŃSTWA SPOLECZNO-POLITYCZNEGO
}

Europa od XIX wieku jest areną dynamicznych przemieszczeń ludności. Współcześnie migracje zostały uznane za zjawisko globalne, które coraz częściej wpływa na przemiany społeczne i kulturowe. Ruchy migracyjne stały się jednym z elementów wywołujących napięcia w państwie przyjmującym oraz wnoszących wkład w rozpad społeczny i osłabienie tożsamości narodowej. Jak zauważył Jef Huysmans migracje można rozpatrywać na płaszczyznach: bezpieczeństwa wewnętrznego, bezpieczeństwa kulturowego i zagrożenia dla państwa opiekuńczego (Huysmans, 2000: 758).

W latach 90. XX wieku do literatury poświęconej zagadnieniom migracji weszło pojęcie sekurytyzacji. Związane było ono z postrzeganiem migracji w kategoriach zagrożeń dla społeczeństwa przyjmującego. W napływie obcych widziano czynnik osłabiający tradycje narodowe i jedność społeczeństwa oraz destabilizujący porządek publiczny i rynek pracy. Twórcy tego pojęcia uznali, iż sekurytyzacja polityki nie musi wynikać z realnego niebezpieczeństwa, ponieważ wystarczy przekonanie o ewentualnym zagrożeniu. Przeświadczenie to, niezależnie od tego czy jest błędne, czy prawidłowe wpływa bowiem na końcową ocenę stanu bezpieczeństwa (Sekściński, 2010: 3).

Sekurytyzacja jest obecnie narzędziem wykorzystywanym w polityce krajowej i unijnej. Widoczne jest to w dziedzinach dotyczących ochrony granic zewnętrznych UE i kontroli napływu cudzoziemców spoza państw członkowskich. Postępująca sekurytyzacja powoduje, że włączenie imigrantów i uchodźców do społeczeństwa przyjmującego staje się trudniejsze. Zmianie ulega postrzeganie osób ubiegających się o status uchodźcy, gdyż coraz rzadziej widzimy w nich ofiary, a częściej jednostki zagrażające naszemu porządkowi i dobrobytowi (Boswell, 2006: 2).

Europa powoli przeradza się w twierdzę coraz trudniejszą do zdobycia. Granice zewnętrzne państw członkowskich UE są lepiej strzeżone, wprowadza się restrykcyjne regulacje prawne dotyczące pobytu, zatrudnienia czy azylu dla obywateli państw trzecich. Przedstawiciele państw UE szukają nowych rozwiązań, które chroniłyby obywateli przed atakami terrorystycznymi i mogłyby zapewnić im stabilizację oraz poczucie bezpieczeństwa we własnej ojczyźnie.

W działania te włączona jest także Polska, która po akcesji do UE przyjmuje coraz więcej cudzoziemców. Sytuacja ta wywoływała i nadal budzi w polskim społeczeństwie wiele emocji. Mają one wydźwięk pozytywny, jak i negatywny. Część Polaków uznaje bowiem obecność obcokrajowców w naszym państwie za pożądaną, inni natomiast upatrują w tym wiele minusów. Do pierwszej grupy należą osoby, które są przekonane, iż pobyt cudzoziemców niesie za sobą przede wszystkim korzyści ekonomiczne, jak na przykład nowe inwestycje, technologie i miejsca pracy. Tego zdania 
było w 1999 r. 59\% ankietowanych przez CBOS, a pięć lat później 46\% (Wenzel, 2004 : 4). Zdecydowanie mniej ankietowanych dostrzega korzyści kulturowe - 13\% w 1999 roku i 27\% w 2004 r. (ibidem: 6). W drugiej grupie znajdują się z kolei podmioty uznające imigrantów za element zagrażający polskiej gospodarce (52\% w 1999 r. i 47\% w 2004 r.). Dla nich obcokrajowcy odpowiedzialni są za napływ taniej siły roboczej, rozwój nierejestrowanego zatrudnienia, nielegalnego handlu oraz przestępczości i zjawisk niepożądanych społecznie, np. żebractwa, handlu narkotykami, konfliktów społecznych - tak uważało 47\% ankietowanych w 1999 r. i 23\% w 2004 r. (ibidem: 8).

W świetle badań CBOS uchodzimy za społeczeństwo otwarte na imigrantów. W 2005 r. 62\% poprało możliwość osiedlenia się cudzoziemców w granicach naszego państwa. Jednocześnie $71 \%$ uznała, że ich nie potrzebujemy, a tylko 13\% opowiedziała się za przyjmowaniem wszystkich uchodźców politycznych (Wenzel, 2005: 2-4). Dostrzec można zatem sprzeczną postawę wśród badanych. Czy jest ona odzwierciedleniem rzeczywistości? Można przyjąć, że tak ponieważ na sposób postrzegania procesów migracyjnych i obcokrajowców wpływ wywiera wiele czynników. Do nich zaliczają się takie elementy, jak: wiek, wykształcenie, poziom życia i zadowolenia z niego, uwarunkowania regionu zamieszkania oraz własne doświadczenia kontaktów $z$ cudzoziemcami. Nie bez znaczenia są także cechy dotyczące samych imigrantów tzn. narodowość, kultura, religia, kolor skóry, status pobytu, cel przyjazdu, kwalifikacje zawodowe i pozycja społeczna.

Współcześnie coraz częściej możemy konfrontować nasze postawy wobec obcokrajowców. Ma to związek nie tylko ze swobodą podróżowania Polaków, ale także $\mathrm{z}$ rosnącą powoli liczbą cudzoziemców w naszym państwie. Ich udział w polskim społeczeństwie nie jest jeszcze tak wysoki, jak w innych państwach Europy Zachodniej. Według danych Eurostatu w 2010 r. wyniósł on 0,1\% (Ausländische, 2011: 2). Wysokość tego współczynnika ma związek z faktem, iż większość imigrantów traktuje Polskę jako państwo tranzytowe w dalszej drodze na zachód Europy (na przykład w 1999 r. wyjechało 99\% obcokrajowców, którzy przybyli do nas w tym roku, a w 2007 r. - 97\%). Niewielu z nich zdecydowało się osiąść w granicach Rzeczypospolitej Polskiej, choć jak pokazują dane statystyczne ich liczba rośnie. Łącznie w latach 1994-2011 decyzję o osiedleniu się na stałe podjęło 183797 obcokrajowców. Od 1994 do 2005 r. pobyt stały w Polsce wybierało między 6500 a 9500 osób rocznie. Później wskaźnik ten wzrósł i najwyższy pułap osiagnął w 2009 r. ponad 17000.

Imigranci zainteresowani pobytem w Polsce byli przede wszystkim Europejczykami. Pochodzili najczęściej z Niemiec, Ukrainy, Wielkiej Brytanii i Francji. Większą popularnością cieszył się pobyt czasowy ${ }^{1}$. Z tej formy korzystało rocznie ponad 40000 osób w latach 1999-2007, a w kolejnych ich liczebność wzrosła do około 66000 (stan na 2011 r.). Powody przyjazdów imigrantów do Polski były bardzo różne. Wśród nich dominowały cele naukowe, chęć znalezienia pracy czy współmałżonka. Do innych pobudek można było zaliczyć także połączenie $\mathrm{z}$ rodziną lub poszukiwanie w Polsce schronienia przed prześladowaniem we własnej ojczyźnie.

1 Zgodnie z metodologią przyjętą przez GUS migracja czasowa definiowana była jako pobyt (poza miejscem stałego przebywania) trwający dłużej niż 2 miesiące, a od 2006 roku ponad 3 miesiące. Migracje zagraniczne ludności 2002 (2003), GUS, Warszawa, s. 28. 
Wykres 1. Migracje do Polski na pobyt stały w latach 1994-2011

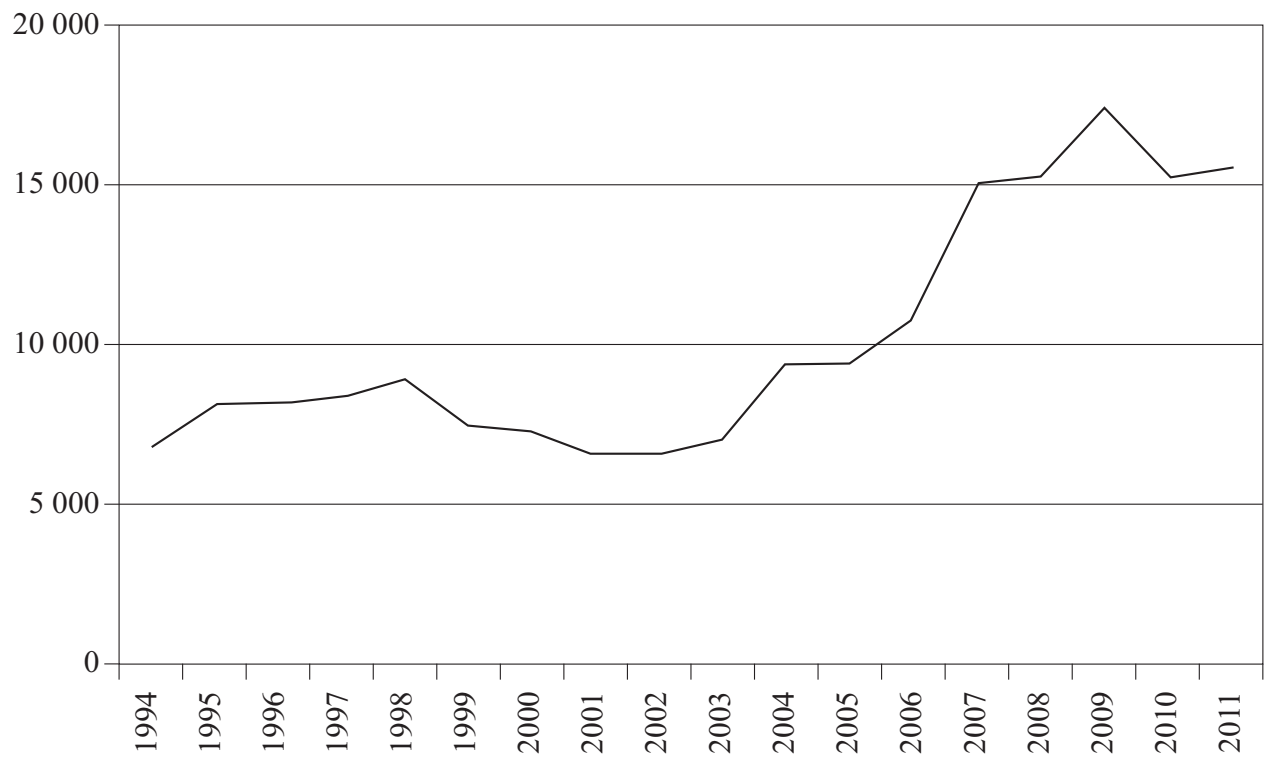

Źródło: Opracowanie na podstawie Rocznik Statystyczny Demografii (lata 1995-1996) oraz Rocznik Demograficzny (lata 1997-2012).

Do końca lat 80 . XX wieku Polska nie odgrywała znaczącej roli w procesach migracyjnych. Rocznie polskie granice przekraczało nie więcej niż 9000000 obcokrajowców (do 1989 r.). Zmiany w tym zakresie odnotowano w latach 90. XX wieku. Wówczas do Polski wjechało ponad 18000000 cudzoziemców, a w 1999 r. już około 90000 000. W kolejnych okresach aż do 2012 r. grono cudzoziemców przybywających do Polski ustabilizowało się między 50000000 a 67000000 rocznie. W polskim ruchu granicznym prym wiedli obywatele państw ościennych. Ich łączny udział wyniósł ponad 90\% ogółu cudzoziemców w latach 1991-2012. Pozostali byli obywatelami UE ${ }^{2}$ (Holandii, Austrii, Francji i Wielkiej Brytanii) oraz państw leżących w Azji, Afryce, Ameryce i Oceanii.

Analizując dane statystyczne, można zaryzykować stwierdzenie, że liczba migrujących do Polski nie spadnie, a wręcz przeciwnie będzie nadal rosła. Migracje są bowiem procesem, którego nie można powstrzymać. Trwa on od wieków, a współcześnie wzmacnia go i przyspiesza postępująca globalizacja. Z tych też powodów potrzebna jest analiza wpływu imigracji na bezpieczeństwo wewnętrzne państwa przyjmującego, abyśmy nie doświadczyli problemów, z jakimi borykają się państwa imigranckie.

Pomimo, iż w państwie polskim procentowy udział imigrantów w społeczeństwie jest niewielki, to jednak obywatele odczuwają zagrożenie ze strony obcych. Sytuacja ta wywiera negatywny wpływ na stopień poczucia ich bezpieczeństwa. Polscy obywatele łączą obecność cudzoziemców najczęściej z:

2 Poza Niemcami i Litwinami od 2004 r. 
- rozwojem drobnej i zorganizowanej przestępczości, prostytucji, handlu ludźmi oraz przemytu narkotyków;

- rozwojem nielegalnej imigracji;

- wzrostem obciążenia budżetu państwa (zwiększeniem wydatków na utrzymanie imigrantów przebywających w ośrodkach dla uchodźców, ośrodkach strzeżonych, wzrostem środków przeznaczanych na Indywidualne Programy Integracyjne, deportację, pokrycie nauki dzieci cudzoziemców w szkołach, utrzymanie instytucji zajmujących się kwestiami migracyjnymi);

- wzrostem bezrobocia, taniej siły roboczej będącej konkurencją dla rodzimych pracowników oraz zatrudnieniem wbrew prawu;

- przejęciem przez cudzoziemców ziemi rolnej.

Należy zwrócić także uwagę, że rosnąca imigracja do Polski może w przyszłości wpłynać na nasze życie społeczno-polityczne. Do tej pory ich aktywność nie doprowadziła co prawda do rozłamów w partiach politycznych czy powstania nowych organizacji o charakterze antyimigracyjnym, ale nie mamy gwarancji, że tak się nie stanie. Obecnie można nawet zauważyć brak zainteresowania ze strony władz państwowych i głównych partii politycznych problematyką migracji zagranicznych. Pojawiające się dyskusje na ten temat $\mathrm{w}$ parlamencie związane są jedynie $\mathrm{z}$ nowelizacją prawa $\mathrm{w}$ tym zakresie. Wyjątek stanowią ugrupowania o charakterze narodowym. Organizacje te są negatywnie nastawione na napływ cudzoziemców do Polski. Swój stosunek do imigrantów wyrażają najczęściej na łamach swoich czasopism lub poprzez organizację różnych przedsięwzięć. Jedno z nich zostało zaplanowane na sierpień 2013 r. Jego inicjatorem był Ruch Narodowy ${ }^{3}$. Akcja została przeprowadzona pod hasłem „Nie chcemy imigranta - chcemy repatrianta” (Brzezińska-Waleszczyk). Bezpośrednim impulsem do działań było przyjęcie przez nasze państwo, w ramach unijnego programu relokacji uchodźców, nielegalnych afrykańskich imigrantów z Malty. Celem przedsięwzięcia podjętego przez Ruch Narodowy było powstrzymanie napływu do Polski cudzoziemców z obcych kręgów cywilizacyjnych, jak na przykład z państw arabskich czy afrykańskich. W opinii inicjatorów akcji sytuacja ta może w przyszłości zagrozić rozwojowi państwa, budowaniu dobrobytu i mieć wpływ na przyszłość kultury, religii i tożsamości narodowej. Zdaniem Roberta Winnickiego z Ruchu Narodowego Polska ma pozostać „krajem słowiańskim oraz chrześcijańskim” (ibidem). Dla zachowania tego charakteru postulował zwiększenie repatriacji z terenów byłego ZSRR (Kazachstanu, Syberii).

Poza ugrupowaniami o charakterze narodowym swoje niezadowolenie z obecności imigrantów wyrażali także mieszkańcy wielu miast. Wśród nich, w ostatnich latach, prym wiedli obywatele Białegostoku. W mieście tym w 2011 r. odnotowano dwanaście przypadków zachowań rasistowskich i ksenofobicznych, rok później osiem, a w 2013 r. dwa (Klimowska, Medek, 2013). Swoją aktywność w tym zakresie wykazywali niektórzy członkowie stowarzyszenia Dzieci Białegostoku, które zrzeszało kibiców Jagiellonii Biatystok.

3 Inicjatywa społeczno-polityczna powołana przez największe organizacje narodowe w 2012 r. Więcej na temat Ruchu Narodowego: http://ruchnarodowy.org. 
Swój niepokój z powodu obecności obcokrajowców manifestowali także mieszkańcy Warszawy. Ich protesty związane były z planami przebudowy domu modlitwy muzułmanów na meczet przy ul. Dymnej $17 \mathrm{w}$ dzielnicy Włochy (Protest mieszkańców Włoch) przez Stowarzyszenie Muzutmańskie Ahmadiyya oraz budowy Ośrodka Kultury Muzułmańskiej wraz z salą modlitwy. Podłożem pierwszej z wymienionych akcji były obawy związane z przekształceniem w przyszłości dzielnicy Włoch w muzułmańską enklawę (Szymanik, 2012). Ostatecznie protesty mieszkańców przyniosły zamierzony skutek, bowiem 8 lutego 2013 r. zarząd dzielnicy Włochy wydał decyzję negatywną w sprawie budowy meczetu (Wojdalski, 2013: 1-2). Swój sprzeciw mieszkańcy Warszawy wyrazili również w sprawie wybudowania Ośrodka Kultury Muzułmańskiej przez Ligę Muzulmańska w RP. Wiele negatywnych emocji wywołała kwestia powiązania inicjatorów tego pomysłu z fundamentalistycznym Bractwem Muzutmańskim. Oponenci powstania tego obiektu zorganizowali manifestację 27 marca 2010 r. Warszawiaków wspierało Stowarzyszenie Europa Przyszłości, które przygotowało plakaty z napisem „Stop islamizacji! Nie meczetowi radykałów!”. Plakaty te były wierną kopią afiszy, które zostały wykorzystane przez inicjatorów referendum w sprawie wprowadzenia do konstytucji Szwajcarii zapisu o zakazie budowy minaretów. Przeciwnicy pomysłu budowy wspomnianego ośrodka zaczęli poszukiwać wsparcia w Internecie. W tym celu założyli profile na portalach społecznościowych (np. na Facebooku), a jeden z radnych PiS Warszawa-Ochota Tymoteusz Pruchnik był inicjatorem założenia strony internetowej meczet-ochota.pl (Fusiecki, 2010). Budowy tego obiektu nie wstrzymano i niebawem nastąi jego otwarcie.

Lęk przed symboliką muzułmańską pojawił się także wśród Poznaniaków w 2009 r. Związany był on z pomysłem autorstwa Joanny Rajkowskiej dotyczącym przekształcenia komina dawnej papierni poznańskiej w minaret. Projekt ten miał stanowić część Festiwalu Teatralnego Malta 2010. W opinii autorki minaret miał być tylko elementem architektury, a nie symbolem religijnym (Wybieralski, 2009). Ostatecznie projektu nie zrealizowano.

Brak sympatii wobec obcokrajowców widoczny był ponadto w Łomży. Część mieszkańców tego miasta przy współpracy z posłem PiS Lechem Kołakowskim wniosła swój wkład w likwidację ośrodka dla uchodźców. W tym celu sformułowali petycję do Urzędu ds. Cudzoziemców, którą podpisały 772 osoby (rok 2010). Ośrodek ostatecznie zamknięto w listopadzie $2010 \mathrm{r}$. Decyzję tę uzasadniano między innymi wzrostem napięć i negatywnych nastrojów wobec cudzoziemców, czego efektem były pobicia dwóch Czeczenek, antyczeczeńskie ulotki w autobusach i obraźliwe wpisy na forach internetowych. Sprawa uchodźców podzieliła lokalną społeczność. Obok przeciwników funkcjonowania ośrodka pojawiła się grupa studentów z Wyższej Szkoły Agrobiznesu w Łomży, która przygotowała apel za utrzymaniem ośrodka. Dokument ten podpisało około 1000 osób (rok 2010). Decyzji jednak nie zmieniono.

Swoje niezadowolenie z obecności obcokrajowców bardzo często wyrażali fani piłki nożnej podczas meczy. Taki wniosek można wysnuć na podstawie informacji zebranych w „Brunatnej Księdze” za lata 2011-2012 (Kornat, 2013). Ofiarami dyskryminacji kibiców byli najczęściej czarnoskórzy piłkarze pochodzący z Nigerii, Zimbabwe, Brazylii i Burkina Faso. Mecze, podczas których obrażano piłkarzy miały miejsce np. w Wagrowcu, Gliwicach, Warszawie, Białymstoku, Strzelcach Opolskich, Opolu, Ja- 
worznie, Nowym Sączu, Płocku, Wrocławiu i Krakowie. Poza stadionem swoją niechęć wobec obcych manifestowano także na murach budynków (Żbikowska, 2013). Demonstrowano ją ponadto poprzez nieodpowiednie zachowanie (naruszenie nietykalności cielesnej) i stosowanie obelżywych słów. Uprzedzenia wobec obcokrajowców widoczne były w filmach (np. Żywot Czeczena) oraz na portalach internetowych. Obiektem ataków były przede wszystkim osoby różniące się od większości kolorem skóry. Poza rasą powodem zajść była również odmienność religijna, a także przekonanie o życiu imigrantów na koszt państwa polskiego (osoby ubiegające się o status uchodźcy).

Niechęć wobec obcych była często wynikiem niedostatecznej integracji imigrantów ze społeczeństwem polskim. Miało to związek z zakwalifikowaniem do programów integracyjnych wąskiego grona cudzoziemców. Poza tym istotne było również przekonanie panujące wśród imigrantów o tymczasowym pobycie w Polsce, a co za tym idzie brak motywacji do integracji i nauki języka polskiego. Wina za ten stan leżała także po stronie Polaków, którzy nie byli przygotowani do współżycia z obcymi. Brakowało nam doświadczenia w tym zakresie, odpowiednich programów oraz kampanii społecznych. Na nasze postawy wpływ wywierała historia naszego państwa, która wymagała od nas podtrzymywania tożsamości i obrony jej przed obcym najeźdźcą i kulturą. Istotne znaczenie dla relacji z cudzoziemcami miał także poziom zadowolenia z sytuacji materialnej, zawodowej i mieszkaniowej oraz fakt bycia społeczeństwem zamkniętym (niemalże jednolitym pod względem narodowościowym i kulturowym).

Jak już wcześniej zaznaczyłam Polacy wiązali napływ obcokrajowców najczęściej ze wzrostem przestępczości, nielegalnej imigracji, nielegalnego zatrudnienia i wykupu polskiej ziemi. W dalszej części artykułu odniosę się do tych kwestii, chcąc pokazać czy wyżej wymienione zagadnienia były i są realnym zagrożeniem, czy też nie.

\section{ROZWÓJ PRZESTĘPCZOŚCI}

Jednym z czynników, który Polacy najczęściej wymieniali jako zjawisko niekorzystne w związku z obecnością cudzoziemców był wzrost przestępczości, w tym zorganizowanej. Rozwój popełnianych czynów prawnie zabronionych przez imigrantów nastapił na przełomie lat 80. i 90. XX wieku. Przestępczość wśród obcokrajowców w Polsce nie osiagnęła poważnych rozmiarów. Od 2002 roku ich udział w ogólnej liczbie osób podejrzanych o popełnienie przestępstw malał, a następnie ustabilizował się na poziomie $0,4 \%{ }^{4}$. Na ogólną liczbę 5987193 podejrzanych w Polsce w latach 2002-2012, cudzoziemcy liczyli 35081 osób.

Przestępstwa, które były udziałem imigrantów popełniano najczęściej w dużych aglomeracjach miejskich, szczególnie w Warszawie. W gronie podejrzanych byli przede wszystkich obywatele państw sąsiadujących z nami. Do nich zaliczali się obywatele Ukrainy, którzy stanowili 34\% ogólnej liczby podejrzanych cudzoziemców w latach 2002-2012 (11 900 osób). Poza nimi problemy z prawem mieli także: Białorusini (4792), Niemcy (2526), Ormianie (2253) i Rosjanie (1998) (Dane statystyczne

4 Dotyczy to lat 2002-2012. Obliczenia własne na podstawie danych statystycznych z Komendy Głównej Policji, http://www.statystyka.policja.pl. 
Komendy). Wśród kategorii zarzucanych czynów dominowały kradzieże oraz przestępstwa rozbójnicze i drogowe (Adamczyk, 2012: 376-386).

Frekwencja cudzoziemców w aresztach śledczych i zakładach karnych nie była wysoka. Pod koniec grudnia 2012 r. stanowili oni $0,7 \%$ ogólnej liczby przebywających w wyżej wymienionych jednostkach penitencjarnych (Roczne sprawozdania Slużb Więziennych). W latach 2002-2004 liczba cudzoziemców przebywająca w aresztach śledczych i zakładach karnych kształtowała się na poziomie powyżej 1000 osób rocznie, a w kolejnych okresach spadła i w 2012 r. wyniosła 564 osoby. Osadzeni pochodzili najczęściej z: Ukrainy, Białorusi i Rosji. Spośród uwięzionych najliczniejszą grupę stanowili cudzoziemcy tymczasowo aresztowani (4774 na 8930 obcokrajowców przebywających w aresztach śledczych i zakładach karnych w latach 2002-2012), a następnie skazani (3595). Najmniej imigrantów osadzonych w jednostkach penitencjarnych było ukaranymi (22) (ibidem).

Poza ogólną przestępczością cudzoziemcy zaznaczyli swoją aktywność w zorganizowanych grupach przestępczych. Rozwój tego rodzaju przestępczości został uznany za jedno z najpoważniejszych zagrożeń mogących zakłócić prawidłowe funkcjonowanie społeczeństwa i wpłynąć na poziom bezpieczeństwa narodowego.

Według danych pochodzących z Centralnego Biura Śledczego Komendy Glównej Policji (CBŚ KGP) aktywność cudzoziemców w zorganizowanych grupach przestępczych nie była duża. W latach 2002-2012 na rozpoznanych 4864 grup, 537, czyli 11\%, miała obcy charakter (pozostałe $89 \%$ stanowiły grupy polskie). Wśród nich najwięcej było grup międzynarodowych - 451, rosyjskojęzycznych - 50 i etnicznych - 36 (Roczne sprawozdania Centralnego Biura, 2002-2012). Członkowie zorganizowanych grup przestępczych pochodzili przede wszystkim z Europy (Ukrainy, Rosji, Litwy, Niemiec, Białorusi), inni także z Azji (Wietnam), Afryki oraz Ameryki Południowej i Północnej (Adamczyk, 2012: 419).

Spośród 4864 grup będących w zainteresowaniu pracowników CBŚ KGP w latach 2002-2012, udało się zlikwidować 1982. Najwięcej wyeliminowano polskich zespołów (1812). W przypadku grup obcych udaremniono działalność 154 grup międzynarodowych, 9 rosyjskojęzycznych i 7 etnicznych (ibidem). W latach 2006-2012 funkcjonariusze CBŚ KGP postawili zarzuty 621 cudzoziemcom, wśród których dominowali: Ukraińcy, Białorusini, Wietnamczycy, Litwini, Rosjanie i Ormianie (ibidem). Prowadzone przez biuro postępowania przygotowawcze dotyczyły przestępstw: narkotykowych, przeciwko życiu i zdrowiu, przeciwko obrotowi gospodarczemu, rozbojów i wymuszeń rozbójniczych oraz zorganizowanej kradzieży samochodów. Skarb Państwa w wyniku aktywności zorganizowanych grup przestępczych poniósł ogromne straty finansowe. Poza tym ich działalność wpłynęła na wzrost poziomu zagrożenia bezpieczeństwa obywateli.

Z przestępczością zorganizowaną powiązany był także proceder handlu ludźmi. Przedmiotem handlu były kobiety (prostytucja), dzieci (nielegalne adopcje, usługi seksualne), wybrane narządy ciała oraz ludzie, stanowiący tanią siłę roboczą. Do początku lat 90. XX wieku problem handlu ludźmi nie był znany w Polsce. Jego rozwój nastąpił wraz z otwarciem granic, zmianami społeczno-politycznymi oraz postępującą pauperyzacją i wzrostem bezrobocia. Polska na mapie handlu ludźmi traktowana była jako kraj pochodzenia ofiar, kraj docelowy oraz miejsce przejściowego pobytu i państwo tranzytowe, przez które transferowane były ofiary. 
Precyzyjne określenie skali zjawiska handlu ludźmi jest niezmiernie trudne. Ma to związek z faktem, iż wiele z przestępstw dotyczących handlu ludźmi nie jest ujawnianych. Ponadto problemów przysparza brak jednej instytucji zajmującej się gromadzeniem danych na ten temat $w$ Polsce oraz metodologii. Statystyki $z$ tego zakresu prowadzą: Policja, Straż Graniczna, Prokuratura Generalna (do marca 2010 r. Prokuratura Krajowa), Ministerstwo Sprawiedliwości i organizacje pozarządowe.

$\mathrm{Na}$ podstawie danych jednej z wymienionych instytucji, a mianowicie Biura do Spraw Przestępczości Zorganizowanej Prokuratury Krajowej (obecnie Prokuratury Generalnej) można stwierdzić, iż w latach 1995-2010 zakończono prowadzenie 765 postępowań przygotowawczych w sprawach o handel ludźmi. W stosunku do 428 z nich wniesiono akty oskarżenia (56\%). W okresie tym zarzuty postawiono 1048 osobom (Dane statystyczne Ministerstwa). Wśród oskarżonych większość stanowili Polacy (około 81\% w latach 2001-2008). Pozostali byli cudzoziemcami. Pochodzili oni z dziesięciu państw, z których najwięcej było obywatelami Bułgarii (47 osób) i Ukrainy (29 osób). Poza nimi oskarżonymi byli także obywatele: Niemiec, Turcji, Wietnamu, Albanii, Hiszpanii, Republiki Mołdowy, Rosji i Rumunii. Łącznie ich liczba w latach 2001-2008 ukształtowała się na poziomie 96 osób (ibidem).

Z informacji zgromadzonych przez Prokuraturę Krajową (i Prokuraturę Generalną) wynikało także, że w latach 1995-2011 pokrzywdzonych zostało 4695 osób. W gronie tym znalazło się 917 cudzoziemców, czyli 19\% ogółu pokrzywdzonych. Ofiarami byli najczęściej obywatele Ukrainy (362) i Białorusi (346) stanowiący łącznie 77\% wszystkich ujawnionych w Polsce ofiar handlu ludźmi wśród cudzoziemców (Zapobieganie handlowi, 2012: 24). Pokrzywdzonymi byli również Bułgarzy (39), Rumunii (37), Mołdowianie (18), Rosjanie (15), Łotysze i Wietnamczycy (po 8).

W celu skutecznego przeciwdziałania handlowi ludźmi dokonano zmian legislacyjnych. 8 września 2010 r. weszła w życie nowelizacja Kodeksu karnego wprowadzająca zmiany w definicji handlu ludźmi (art. 115 § 22 k.k.) i interpretująca pojęcie niewolnictwa (art. $115 \S 23$ k.k.). Ponadto w kodeksie umieszczono nowy artykuł 189a określający wysokość kary pozbawienia wolności dla osoby dopuszczającej się handlu ludźmi (minimum 3 lata) oraz czyniącej przygotowania do popełnienia tego przestępstwa (od 3 miesięcy do 5 lat). Należy także nadmienić, iż Polska jest stroną wielu dokumentów międzynarodowych $\mathrm{w}$ zakresie przeciwdziałania handlowi ludźmi. Bierze udział w projektach o charakterze międzynarodowym, bilateralnym oraz wdraża w życie programy zwalczania i zapobiegania handlowi ludźmi.

Podsumowując powyższe rozważania można stwierdzić, iż powszechna obawa łączenia pobytu cudzoziemców w Polsce ze wzrostem przestępczości nie znajduje uzasadnienia. Przeczą temu dane statystyczne gromadzone przez różne instytucje publiczne. Należy jednak mieć na uwadze fakt, iż wiele przestępstw z udziałem cudzoziemców nie jest ujawnianych.

\section{NIELEGALNA IMIGRACJA}

Polska narażona była i nadal jest na negatywne zjawisko nielegalnej imigracji. Związane jest ono między innymi z przekraczaniem granicy wbrew przepisom oraz or- 
ganizowaniem i ułatwianiem nielegalnym imigrantom przekroczenia granicy wbrew prawu. Rozwojowi nielegalnej imigracji sprzyjają przede wszystkim: położenie Polski w centrum Europy, przez którą biegną główne szlaki przerzutu cudzoziemców, integracja ze strukturami unijnymi, globalizacja oraz trudna sytuacja w państwach azjatyckich i afrykańskich wypychająca obywateli poza granice ojczyzny.

Jak wynika z badań CBOS Polacy (w 60\%) uważali przemyt ludzi przez granicę za bardzo poważny problem (Pietrzyk, 2004: 11). Większość (48\%) zgadzała się ze stwierdzeniem, że proceder ten stale rośnie (71\%) i zwiększy się wraz z integracją z UE (ibidem: 2,10 ). Obawy na temat niekontrolowanego napływu imigrantów były słuszne, ponieważ pociaggały za sobą zjawiska zagrażające bezpieczeństwu. Do nich Straż Graniczna w 2012 r. zaliczyła osiem różnych obszarów. Wśród nich znalazły się: naruszenie zasad wjazdu do Polski, fałszowanie dokumentów podróży, nadużycia procedury abolicyjnej, nadużycia wizowe, nadużycia procedur związanych z nadaniem statusu uchodźcy i zatrudnieniem cudzoziemców, zawieranie fikcyjnych związków małżeńskich i podejmowanie fikcyjnej nauki (Raport, 2013: 45-47).

W celu uniknięcia lub zminimalizowania konsekwencji wskazanych wyżej zagrożeń podjęto szereg działań na płaszczyźnie krajowej, jak i unijnej. Dotyczyły one między innymi: rozwoju prawodawstwa w zakresie polityki migracyjnej i azylowej, zawierania umów readmisyjnych, przygotowania i realizacji planów działania na rzecz walki z nielegalną imigracją i ochroną granic zewnętrznych UE, tworzenia baz danych zawierających informacje na temat osób z państw trzecich, współpracy operacyjnej w zakresie zwalczania przestępczości międzynarodowej oraz powołania instytucji stojących na straży ochrony przed niekontrolowanym napływem imigrantów, towarów i przestępczością zorganizowaną (Europejska Agencja Zarzqdzania Wspótpraca Operacyjna na Zewnętrznych Granicach Państw Członkowskich, FRONTEX). Do najnowszych pomysłów w tym zakresie należało uruchomienie Europejskiego Systemu Nadzorowania Granic (EUROSUR). Projekt ten ma wspierać państwa członkowskie w ograniczaniu nielegalnej imigracji, wzmocnić bezpieczeństwo wewnętrzne w UE oraz zmniejszyć liczbę zgonów wśród migrantów nielegalnie forsujących granice państw członkowskich.

Walka z nielegalną migracją w Polsce stała się istotna po wejściu naszego kraju do struktur unijnych. Największą uwagę skupiono na wschodniej granicy Polski, która po 2004 r. stała się zewnętrzną granicą UE. Obcokrajowcy decydowali się na nielegalne przekroczenie polskiej granicy z wielu powodów, do których zaliczały się na przykład: odmówienie wydania polskiej wizy lub wjazdu na teren RP, przemyt, brak dokumentów uprawniających do przekroczenia granicy lub przekraczanie granicy na podstawie sfałszowanego albo cudzego dokumentu lub posiadanie narkotyków, poszukiwanie listem gończym lub figurowanie w wykazie osób niepożądanych w Polsce. Nielegalna migracja należała do dochodowych form działalności zorganizowanych grup przestępczych.

Na początku lat 90. XX wieku zjawisko to osiągnęło niespotykane wcześniej rozmiary. Najwyższą liczbę zatrzymań za nielegalne usiłowanie lub przekroczenie granicy odnotowano w 1992 r. Wówczas zatrzymano 33581 osób (w tym także Polaków - Adamczyk, 2012: 403). W następnym latach liczba cudzoziemców schwytanych przez funkcjonariuszy Służb Granicznych spadła. W latach 2002-2012 utrzymywała się na poziomie od 2000 do 3000 rocznie, poza dwoma wyjątkami. Do nich należały rok 2004 i 2008 . W pierwszym okresie zatrzymano 4472 obcokrajowców. $80 \%$ tych za- 
trzymań przypadła na granicę wewnętrzną UE - szczególnie z Niemcami. Z kolei w drugim okresie ujęto 5574 cudzoziemców, z czego $61 \%$ na granicy zewnętrznej UE (najwięcej na odcinku polsko-ukraińskim).

Wykres 2. Zatrzymania za nielegalne usilowanie lub przekroczenie granicy w latach 2002-2012

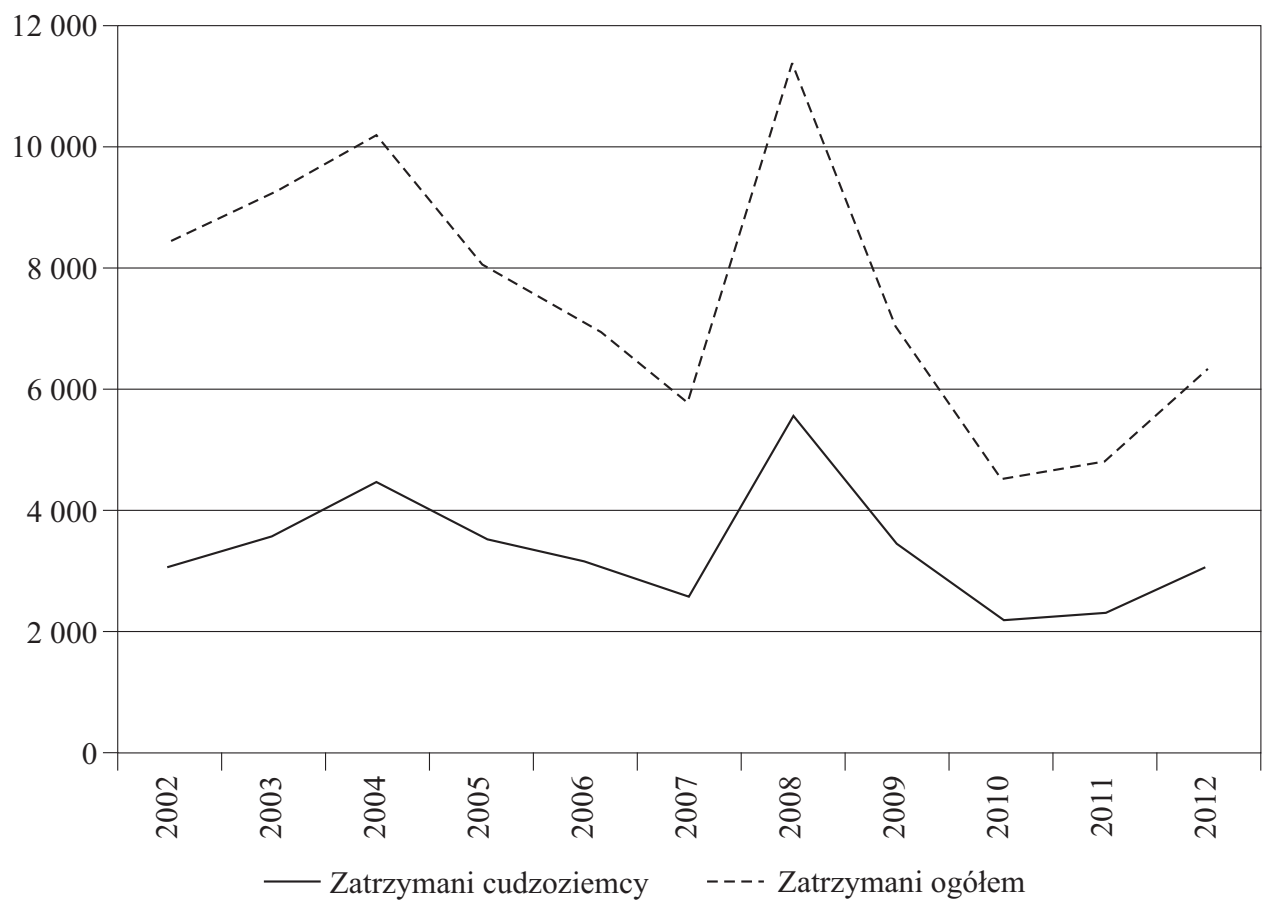

Źródło: Opracowanie własne na podstawie rocznych sprawozdań Komendy Głównej Straży Granicznej za lata 2003-2012.

Wśród nielegalnych imigrantów dominowali obywatele Ukrainy. W latach 2002-2012 zatrzymano łącznie 15206 Ukraińców, którzy stanowili 41\% wszystkich ujętych w tym okresie cudzoziemców (Roczne sprawozdania z działalności Komendy). Dalsze miejsca zajęli: Rosjanie (4036), Czesi (2101, z czego 95\% w latach 2002-2007), Mołdowianie (1881), Wietnamczycy (1681), Białorusini (1319) i Gruzini (998).

Część cudzoziemców, która nielegalnie przekroczyła granice oraz nie dopełniła obowiązujących warunków dotyczących pobytu podlegała procedurze readmisji. W ramach readmisji dominowały przekazania cudzoziemców z Polski. Łącznie w latach 2002-2012 uczyniono to w stosunku do 43449 osób. Z danych Służb Granicznych wynikało, iż najwięcej przekazań w latach 2004-2012 (tj. 91\%) miało miejsce na zewnętrznej granicy UE (ibidem), a dokładnie granicy polsko-ukraińskiej.

Znacznie mniej obcokrajowców Polska przyjęła z terenów innych państw. Od 2002 do 2012 r. przekazano nam 20662 imigrantów. W okresie tym najwięcej cudzoziemców przyjęliśmy od służb niemieckich (10 332 osoby), którzy stanowili 50\% wszystkich podlegających readmisji do Polski (ibidem). 
Wykres 3. Przekazani do Polski i z Polski w latach 2002-2012

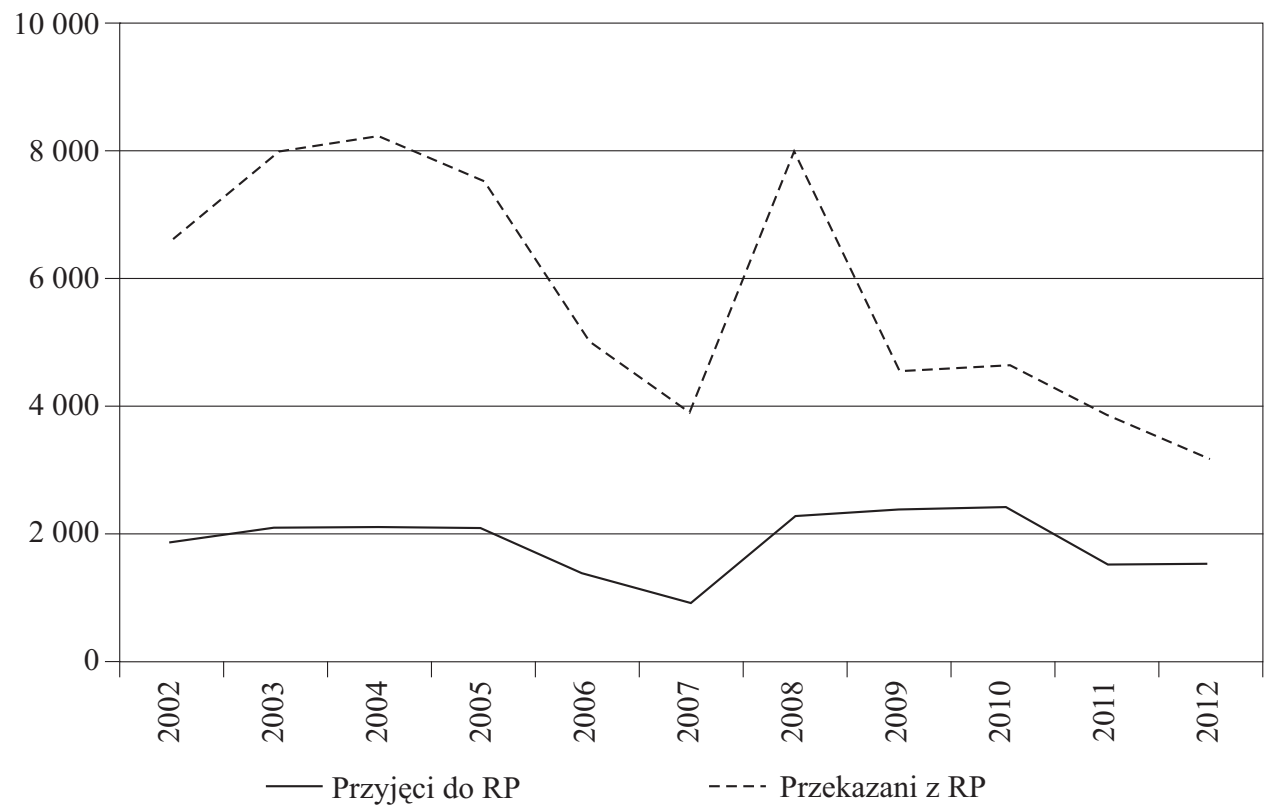

Źródło: Opracowanie własne na podstawie rocznych sprawozdań Komendy Głównej Straży Granicznej za lata 2003-2012.

Walcząc z nielegalną imigracją korzystaliśmy, poza procedurą readmisji, z instytucji wydalenia. Ustawa o cudzoziemcach w art. 88 ust. 1 przewiduje dwanaście powodów uprawniających do wydania decyzji o wydaleniu obcokrajowca z terenów RP. W latach 2002-2012 na podstawie powyższego artykułu wydalono 46865 osób (Dane statystyczne Urzędu). Należy jednak podkreślić, iż w badanym okresie poziom wydalanych cudzoziemców obniżał się i na przykład w 2002 r. wyniósł on 8280 osób, a w 2012 r. już tylko 967. Wydalano najczęściej obywateli: Ukrainy (19 589, czyli 42\%), Wietnamu (3585), Rosji (3341), Armenii (2708) i Republiki Mołdowy (2490).

$\mathrm{W}$ trosce o ochronę przed niepożądanymi imigrantami stosowano w Polsce także instytucję odmowy wjazdu. Zgodnie z art. 21 ust. 1 ustawy o cudzoziemcach z 2011 r. można wyróżnić jedenaście sytuacji, w których istnieje uzasadniona konieczność zastosowania przez komendanta placówki Straży Granicznej odmowy wjazdu. Wśród nich są na przykład: brak ważnych dokumentów lub wizy, brak wystarczających środków utrzymania w odniesieniu do długości i celu planowanego pobytu, figurowanie w spisie osób niepożądanych w RP czy posługiwanie się sfałszowanymi dokumentami. Odwołując się do powyższego zapisu ustawowego, w okresie od 2002 do 2012 r., odmówiono wjazdu do Polski 400925 obcokrajowcom. W gronie tym dominowali obywatele: Ukrainy (148 447, czyli 37\%), Białorusi (85 809) i Rosji (67 350). Warto także zauważyć, iż od 2009 r. znacząco wzrosła liczba Gruzinów, którym odmówiono wjazdu na terytorium RP. W latach 2009-2012 ich udział w ogólnej liczbie odmów wjazdu do Polski wyniósł 22\%. 


\section{NIELEGALNE ZATRUDNIENIE}

Zatrudnienie cudzoziemców wbrew prawu było najczęściej wymienianym przez Polaków zagrożeniem w dziedzinie ekonomii w badaniach CBOS. Rozwojowi ,pracy na czarno" sprzyjało wiele czynników, wśród których można wymienić: brak chętnych Polaków do pracy, akceptacja w polskim społeczeństwie zjawiska „pracy na czarno”, wysokie koszty pracy w Polsce, nieznajomość polskiego prawa pracy czy nieuregulowany status pobytu obcokrajowca.

Nierejestrowana praca imigrantów dotyczyła najczęściej zajęć z tzw. grupy 3D czyli brudne, niebezpieczne i trudne. Czynności wykonywane przez cudzoziemców nie wymagały zazwyczaj wysokich kwalifikacji. Była to praca o niskim prestiżu społecznym i niewielkich zarobkach wykonywana podczas krótkich pobytów w naszym kraju, trwających z reguły od 1 do 3 miesięcy. Zazwyczaj praca miała charakter dorywczy. Wykonywana była ona przede wszystkim w takich działach, jak: rolnictwo i ogrodnictwo, handel hurtowy i detaliczny, usługi i budownictwo. Firmy, które najczęściej decydowały się na angaż obcokrajowców wbrew prawu liczyły zazwyczaj do 9 pracowników.

W celu ograniczenia nielegalnej imigracji zarobkowej wprowadzono w życie w 2012 roku Ustawe o skutkach powierzenia wykonywania pracy cudzoziemcom przebywajacym wbrew przepisom na terytorium $R P$. Uchwalenie tego aktu wynikało $\mathrm{z}$ implementacji na grunt prawa krajowego postanowień dyrektywy Parlamentu Europejskiego i Rady 2009/52/WE z dnia 18 czerwca 2009 roku przewidujacej minimalne normy $w$ odniesieniu do kar i środków stosowanych wobec pracodawców zatrudniajacych nielegalnie przebywajacych obywateli krajów trzecich. Dzięki nowym rozwiązaniom prawnym zwiększono skuteczność kontroli zatrudnienia imigrantów ${ }^{5}$ przez nałożenie na pracodawców obowiązku sprawdzenia legalności pobytu zagranicznych pracowników w Polsce przez przedłożenie przed rozpoczęciem pracy ważnego dokumentu uprawniającego do pobytu w Polsce oraz przechowywania kopii takiego dokumentu przez cały okres wykonywania pracy przez obcokrajowca.

Katalog zachowań podlegających penalizacji na podstawie wspomnianego aktu prawnego określony został dość szeroko. Stosownie do brzmienia ustawy, karze podlega między innymi: powierzenie w tym samym czasie wykonywania pracy wielu cudzoziemcom nielegalnie przebywającym na terytorium RP, powierzenie wykonywania pracy małoletniemu cudzoziemcowi przebywającemu bez ważnego dokumentu uprawniającego do pobytu na terytorium RP oraz uporczywe powierzanie wykonywania pracy cudzoziemcowi nielegalnie przebywającemu na terytorium RP (art. 9). Za niedostosowanie się pracodawców do przepisów ustawy grozi kara grzywny lub pozbawienia wolności do lat 3 . W przypadku skazania za niezgodne z ustawą zatrudnianie cudzoziemców ustawodawca przewidział dodatkowe sankcje w postaci: pozbawienia dostępu przez pracodawcę do środków europejskich pochodzących z funduszy strukturalnych na okres od 1 roku do 5 lat, zwrotu instrumentów pomocy publicznej uzy-

5 Ustawa dotyczy obcokrajowców zatrudnianych na podstawie umów o pracę oraz umów cywilnoprawnych, którzy nie są obywatelami krajów Unii Europejskiej, Europejskiego Obszaru Gospodarczego czy Konfederacji Szwajcarskiej i przebywają w Polsce nielegalnie. 
skanych w okresie 12 miesięcy poprzedzających wykrycie nielegalnego zatrudnienia, jak i wykluczenie z postępowań o udzielenie zamówienia publicznego przez okres 1 roku.

W latach 1999-2006 liczba stwierdzonych przypadków nielegalnego zatrudnienia (Ustawa, 2004: art. 2.1) cudzoziemców wyniosła łącznie 14814 (Adamczyk, 2012: 294). Średnio w tym okresie co roku wykrywano i udokumentowano niezgodne z prawem zatrudnienie 1851 imigrantów. W następnych latach ich liczba spadła i wyniosła 3596 (w okresie 2008-2012), czyli średnio 719 osób na rok (Roczne sprawozdania $z$ działalności Państwowej Inspekcji). Zmniejszenie rozmiarów tego zjawiska mogło mieć związek z liberalizacją przepisów dotyczących angażu obcokrajowców w Polsce, uproszczeniem procedur wydawania zezwoleń i obniżeniem opłaty za wydanie zezwolenia na pracę.

Kontrole wykazały, iż najczęściej na pracę wbrew przepisom, w latach 2003-2006, decydowali się obywatele: Ukrainy (3696), Białorusi (1746), Bułgarii (665) i Armenii (448) (Adamczyk, 2012: 296-297, tab. 81). W latach 2008-2012 największą grupę nielegalnie zatrudnionych nadal stanowili Ukraińcy (1995), a na dalszym miejscach uplasowali się obywatele ChRL (261), Macedonii (162) i Wietnamu (158) (Roczne sprawozdania z dziatalności Państwowej Inspekcji). Należy jednak podkreślić, iż od 2008 r. zaobserwowano spadek liczby wykrytych przypadków nielegalnego podejmowania pracy przez Ukraińców, Białorusinów i Rosjan (co mogło mieć związek z łagodzeniem zasad zatrudnienia obywateli tych trzech państw przy podejmowaniu prac sezonowych w Polsce).

Problem nielegalnego zatrudniania cudzoziemców dotyczył dużych aglomeracji miejskich. W latach 2001-2006 najwięcej przypadków nielegalnego wykonywania pracy przez cudzoziemców odnosiło się do województw: lubelskiego (4276), mazowieckiego (1611), dolnośląskiego (1402) (Adamczyk, 2012: 299, tab. 83). Z kolei w okresie 2009-2012 najwięcej cudzoziemców świadczących pracę nielegalnie stwierdzono w województwach: śląskim (487), dolnośląskim (445) i łódzkim (400). Imigranci wbrew prawu angażowani byli w sekcjach: handel hurtowy i detaliczny, usługi, budownictwo w latach 2003-2006 oraz budownictwo, przetwórstwo przemysłowe oraz rolnictwo, leśnictwo, łowiectwo od 2009 do 2012 r. (Roczne sprawozdania z działalności Państwowej Inspekcji).

W zakresie legalności zatrudnienia najczęściej stwierdzonymi nieprawidłowościami były: brak posiadania wymaganego zezwolenia na pracę przez cudzoziemca, wykonywanie pracy na innym stanowisku i warunkach niż te które zostały określone w zezwoleniu na pracę oraz powierzenie pracy bez uprzedniego zawarcia umowy o pracę lub umowy cywilnoprawnej.

Wyeliminowanie zjawiska nielegalnego zatrudniania cudzoziemców należało do trudnych przedsięwzięć. Z pewnością konieczne wydaje się kontynuowanie zmian w polityce zatrudnienia i imigracyjnej państwa. Już dzisiaj widoczne są pozytywne efekty wprowadzenia uproszczonych procedur zatrudniania obywateli Ukrainy, Rosji, Białorusi, Republiki Mołdowy i Gruzji. Przyszłość pokaże również czy zaostrzenie sankcji dla pracodawców zatrudniających nielegalnie imigrantów przyniesie korzystne skutki. 


\section{ZAGROŻENIE WYKUPEM ZIEMI}

Jednym z wielu negatywnych skutków procesu napływu imigrantów do Polski była również obawa przejęcia przez obcy kapitał polskiej ziemi. Zagadnienie to wywoływało lęk zarówno przed przystapieniem Polski do UE, jak i dziewięć lat po akcesji. W opinii społecznej kwestię tę utożsamiano bowiem nie tylko z utratą majątku, ale także suwerenności i tożsamości narodowej.

W pierwszym wspomnianym okresie tzw. „spór o ziemię” towarzyszył negocjacjom w obszarze Swobodny przeplyw kapitału. Uczucie zagrożenia podtrzymywały najczęściej partie prawicowe i związane z nimi środki masowego przekazu. W obronie polskiej ziemi wystąpili członkowie dwóch ugrupowań, a mianowicie Ligi Polskich Rodzin i Samoobrony. Pierwsza partia wystawiła w Sejmie RP Ztota księgę obrońców ziemi, a druga zapowiedziała złożenie wniosku w sprawie wotum nieufności dla Jarosława Kalinowskiego oraz przeprowadzenia referendum ogólnokrajowego na temat sprzedaży polskiej ziemi cudzoziemcom (dwa wnioski w tej sprawie z marca i listopada 2002 r. nie uzyskały akceptacji parlamentu).

W trakcie trwania negocjacji, jak i po ich zakończeniu ogromną wrażliwość na kwestie związane ze sprzedażą nieruchomości cudzoziemcom wykazała polska opinia publiczna. Na postawę Polaków wobec tego zagadnienia wpływ wywarły czynniki natury historycznej, formalno-prawnej (nieuregulowana sprawa ksiag wieczystych nieruchomości na Ziemiach Odzyskanych, brak planów zagospodarowania przestrzennego określających charakter danej nieruchomości, nieaktualizowana ewidencja gruntów i budynków) i ekonomicznej (dysproporcje cenowe nieruchomości między Polską a państwami UE, wzrost konkurencyjności).

Lęk przed utratą nieruchomości wywoływał uczucie zagrożenia, które narastało wraz ze zbliżającym się terminem akcesji Polski do UE. W grupie odczuwającej największy strach znaleźli się mieszkańcy wsi i rolnicy. Oni byli największymi sceptykami członkostwa Polski w strukturach unijnych. Według badań przeprowadzonych w 2002 r. przez Instytut Spraw Publicznych obawy przed integracją wyraziło ponad $60 \%$ społeczności wiejskiej, a niechęć $22 \%$ badanych (Mieszkańcy wsi, 2002). Uczucie strachu wśród mieszkańców wsi i rolników związane było z możliwością upadku gospodarstw rolnych, wykupienia ziemi przez zagraniczny kapitał oraz z trudnościami związanymi ze zbyciem produktów rolnych. W mniejszym stopniu bali się oni ograniczenia suwerenności przez państwo, osłabienia patriotyzmu czy obniżenia religijności Polaków (ibidem: 22).

Największe obawy przed wykupem ziemi wykazywali rolnicy $(87 \%$ w $1999 \mathrm{r}$. i $84 \%$ w 2002 r.) i mieszkańcy wsi (79\% w 1999 r. i 80\% w 2002 r.). Tylko nieliczni (23\% w 1999 r. i 13\% w 2002 r.) byli gotowi sprzedać ziemię cudzoziemcowi (ibidem: 13). Większą popularnością cieszyła się natomiast dzierżawa gruntów (76\% w $1999 \mathrm{r}$. i $60 \%$ w 2002 r.).

Przed przystapieniem Polski do Unii Europejskiej argument wykupu polskiego majątku przez obcy kapitał był dla 54\% ankietowanych wystarczający, aby opowiedzieć się przeciwko integracji (Strzeszewski, 2003). Obawy wiązały się często z poczuciem zagrożenia ze strony niemieckich inwestorów. Niepokój przed zachodnim sąsiadem wynikał także z nierównego rozwoju ekonomicznego obu państw. Stereoty- 
powy obraz bogatego Niemca i biednego Polaka wywierał wpływ na stosunek do tego zagadnienia. Poza tym niskie ceny polskich nieruchomości w porównaniu z obowiązującymi w Niemczech nie napawały optymizmem. Na wzajemne stosunki wpływ wywierała również przeszłość.

W świetle danych statystycznych zebranych przez ministra spraw wewnętrznych i Agencje Nieruchomości Rolnych należy stwierdzić, iż obawy Polaków związane z przejęciem przez cudzoziemców polskiej ziemi nie potwierdziły się. Udział gruntów ornych w ogólnej sprzedaży nieruchomości nie był wysoki. W latach 1990-2012 cudzoziemcy zakupili na podstawie zezwoleń lub bez obowiązku uzyskania zezwolenia nieruchomości gruntowe o powierzchni 45900 hektarów, co stanowi $0,15 \%$ powierzchni kraju (Petny zapis, 2013: 7).

Wielkość gruntów nabytych przez cudzoziemców z Zasobu Własności Rolnej Skarbu Państwa również nie była wysoka. W latach 1992-2007 Agencja Nieruchomości Rolnych (ANR) sprzedała obcokrajowcom 0,08\% (czyli 1361 ha) wszystkich zbytych gruntów (Adamczyk, 2012: 361).

Emocje związane z liberalizacją zakupu nieruchomości przez obcokrajowców po akcesji do UE opadły. Powróciły ponownie na przełomie 2012 i 2013 r. Miały one związek z wprowadzeniem od 1 maja 2016 r. pełnej swobody w nabywaniu nieruchomości rolnych i leśnych przez obywateli UE. Swój niepokój pierwsi wyrazili rolnicy z zachodniopomorskiego. W grudniu 2012 r. rozpoczęli protesty, do których później dołączyli rolnicy z Ziemi Radomskiej oraz województwa dolnośląskiego. W ramach akcji blokowano oddział Agencji Nieruchomości Rolnych w Szczecinie i drogi krajowe. Komitet protestacyjny domagał się wstrzymania przetargów ograniczonych z powodu wykupu ziem przez tzw. „słupów”, którzy nabywali ją dla cudzoziemców na podstawie umów cywilnoprawnych ${ }^{6}$. Protestujący nie zgadzali się także z zawyżaniem cen za hektar ziemi. Opowiadali się ponadto za przyspieszeniem tempa sprzedaży ziemi przez ANR Polakom na preferencyjnych zasadach oraz sprawdzeniem podejrzanych transakcji, w których zachodzi prawdopodobieństwo przeniesienia prawa własności na obcokrajowca. Zdaniem rolników z zachodniopomorskiego spora część ziem już należy do obcych (Niemców, Holendrów), a dane ANR nie oddają skali zjawiska. W opinii Edwarda Kosmali, członka Rady Krajowej NSZZ Rolników Indywidualnych „Solidarność” straciliśmy już jedno województwo z setkami tysięcy hektarów (Posiedzenie, 2013: 9).

W rozwiązanie sporu zaangażowali się: minister rolnictwa i rozwoju wsi, prezes ANR oraz senacka Komisja Rolnictwa i Rozwoju Wsi. Swój udział w tym wzięli także członkowie Prawa i Sprawiedliwości z europosłem Januszem Wojciechowskim na czele, którzy 1 lutego 2013 r. złożyli Marszałkowi Sejmu RP projekt ustawy o zmianie ustawy o kształtowaniu ustroju rolnego odnoszący się do powyższych zagadnień (Druk nr 1659, 2013).

11 stycznia 2013 r. odstapiono od dalszych protestów w konsekwencji podpisania ustaleń między ministrem rolnictwa i rozwoju wsi, prezesem ANR a przedstawicielami Międzyzwiqzkowego Komitetu Protestacyjnego Rolników Województwa Zachodniopo-

\footnotetext{
${ }^{6}$ Za dokonanie transakcji osoby podstawione otrzymywały gratyfikację pieniężną.
} 
morskiego (Ustalenia 2013). Przyjęcie tego dokumentu obniżyło z pewnością napięcia wywołane zbliżaniem się daty nieskrępowanego nabywania ziemi przez cudzoziemców, ale nie zlikwidowało obaw polskich rolników przed ich zachodnioeuropejskimi partnerami. W miarę zbliżania się daty 1 maja 2016 r. zagadnienie swobodnego nabywania ziemi przez obywateli UE może powrócić.

$$
* * *
$$

We współczesnym świecie wśród wielu zagrożeń związanych z bezpieczeństwem państwa i jego obywateli wyróżnia się problem migracji zagranicznych i konsekwencji, jakie niesie za sobą to zjawisko. Obecnie obserwujemy wzrost nietolerancji i nieufności. Ataki terrorystyczne, niepokoje na Bliskim Wschodzie i w Afryce wzmacniają napięcia między narodami. „Zderzenie cywilizacji” nie wytrzymuje próby czasu. Społeczności o różnych kulturach i religii mają problemy ze wspólną egzystencją, co powoduje że żyją obok siebie.

Europa, podobnie jak Polska, stoi przed wieloma wyzwaniami społeczno-ekonomicznymi, jak: starzenie się społeczeństwa, brak pracowników, zachowanie trwałości systemu zabezpieczeń społecznych i wzrost konkurencyjności. Może okazać się, że jednym z podstawowych rozwiązań będzie otwarcie się na legalnych imigrantów z różnych kręgów kulturowych. Sytuacja ta będzie wymagała zgodnego ułożenie wzajemnych stosunków między społeczeństwem przyjmującym a przybyszami dla dobra wyższych wartości. Potrzebna będzie odpowiednia polityka integracyjna, która zminimalizuje negatywne odczucia w związku z obecnością obcych z jednej strony. $Z$ drugiej natomiast zapewni cudzoziemcom dogodne warunki do integracji z polskim społeczeństwem i zwiększy ich uczestnictwo w życiu społecznym oraz politycznym.

\section{Bibliografia}

Adamczyk A. (2012), Społeczno-polityczne implikacje imigracji do Polski w latach 1989-2007, Poznań.

Ausländische Staatsangehörige machen 6,5\% der EU27 Bevölkerung im Jahr 2010 (14. Juli 2011), http://epp.eurostat.ec.europa.eu/cache/ITY_PUBLIC/3-14072011-BP/DE/3-14072011-BP-DE.PDF (dostęp: 4.09.2013).

Dane statystyczne Komendy Głównej Policji, http://www.kgp.gov.pl.

Dane statystyczne Ministerstwa Spraw Wewnętrznych, https://www.msw.gov.pl/pl/bezpieczenstwo/ przeciwdzialanie-handl/dane-statystyczne/9321,Dane-statystyczne.html (dostęp: 15.09.2013).

Dane statystyczne Urzędu do Spraw Cudzoziemców, lata 1995-2012.

Druk nr 1659 z dnia 1 lutego 2013 roku o zmianie ustawy o ksztaltowaniu ustroju rolnego, http://orka.sejm.gov.p1/Druki7ka.nsf/0/DBD2D835B538A281C1257BD5002BECC8/\%24File/ 1659.pdf (dostęp: 4.09.2013).

Dyrektywa Parlamentu Europejskiego i Rady 2009/52/WE z dnia 18 czerwca 2009 roku przewidujaca minimalne normy w odniesieniu do kar i środków stosowanych wobec pracodawców zatrudniajacych nielegalnie przebywajacych obywateli krajów trzecich, Dz. U. UE. L. 2009, Nr 168, poz. 24. 
Boswell Ch. (2006), Migration Control in Europe after 9/11: Explaining the Absence of Securitization, www.utexas.edu/cola/centers/european_studies/_files/pdf/immigration-policy-conference/boswell.pdf 22.07.2009 (dostęp: 15.09.2013).

Brzezińska-Waleszczyk M., Nowa akcja narodowców. „Nie zgadzamy się na przyjmowanie przez Polskę imigrantów z obcych kręgów cywilizacyjnych", http://www.fronda.pl/a/nowa-akcja-narodowcow-nie-zgadzamy-sie-na-przyjmowanie-przez-polske-imigrantow-z-obcych-kregow-cywilizacyjnych,30031.html (dostęp: 15.09.2013).

Fusiecki J. (2010), Wojna o meczet na Ochocie przeniosła się do Internetu, http://warszawa.gazeta.pl/ warszawa/1,34889,7822082,Wojna_o_meczet_na_Ochocie_przeniosla_sie_do_internetu.html (dostęp: 18.09.2013).

Huysmans J. (2000), The European Union and securitization of migration, ,Journal of Common Market Studies", Vol. 38, No. 5.

Jok (2010), Więcej za uchodźcami niż przeciwko nim, http://miasta.gazeta.pl/miasto/1,96987, 7838750,Wiecej_za_uchodzcami_niz_przeciwko_nim.html (dostęp: 18.08.2013).

Klimowska J., Medek J. (2013), Białystok. Tu obcych wita się ogniem, http://wyborcza.pl/piatekekstra/ 1,132513,13962731,Bialystok_Tu_obcych_wita_sie_ogniem.html\#TRrelSST(dostęp: 18.08.2013).

Kornat M. (2013), Brunatna ksiega 2011-2012, Warszawa

Mieszkańcy wsi o integracji europejskiej: opinie, wiedza, poinformowanie. Główne wyniki badań (2002), Warszawa, http://www.agro-info.org.pl/Mieszkancy_wsi_o_integracji.pdf (dostęp: 15.12.2006).

Migracje zagraniczne ludności 2002 (2003), GUS, Warszawa.

Petny zapis przebiegu posiedzenia Komisji Spraw Wewnętrznych (Nr 82) z dnia 7 maja 2013 roku, Kancelaria Sejmu. Biuro Komisji Sejmowych, http://orka.sejm.gov.pl/zapisy7.nsf/0/ B02309A52ED59566C1257B670049BFAF/\%24File/0175907.pdf (dostęp: 4.09.2013).

Pietrzak A. (2004), Przemycanie ludzi do Polski, CBOS Komunikat z badań, Warszawa.

Posiedzenie Komisji Rolnictwa i Rozwoju Wsi nr 51 w dniu 10 stycznia 2013 roku, Senat RP, Zapis stenograficzny, http://www.senat.gov.pl/prace/komisje-senackie/posiedzenia,9,3,komisja-rolnictwa-i-rozwoju-wsi.html (dostęp: 18.08.2013).

Protest mieszkańców Włoch przeciwko budowie meczetu wraz z zapleczem biurowo-ustugowym przy ul. Dymnej we Włochach, http://www.willawlochy.org.pl/stowarzyszenie/14-interwencje/30-inicjatywa-mieszkacow-wloch-w-sprawie-meczetu (dostęp: 28.08.2013).

Raport na temat realizacji polityki w zakresie migracji i azylu (2013), Krajowy Punkt Kontaktowy Europejskiej Sieci Migracyjnej w Polsce, Warszawa.

Roczne sprawozdania Centralnego Biura Śledczego Komendy Głównej Policji, lata 2002-2012.

Roczne sprawozdania Komendy Głównej Straży Granicznej, lata 2003-2012.

Roczne sprawozdania Państwowej Inspekcji Pracy, 2008-2012.

Roczne sprawozdania Stużb Więziennych, http://www.sw.gov.pl.

Rocznik Demograficzny, 1997-2012.

Rocznik Statystyczny Demografii, 1995-1996.

Sekściński A. (2010), Polityczne uwarunkowania bezpieczeństwa wewnętrznego Polski w XXI wieku, $\mathrm{http} / /$ www.fsap.pl/documents/publications/Referat_Polityczne_uwarunkowania_bezpiecze\% C5\%84stwa_wewn_Polski_w_XXI_wieku.pdf (dostęp: 18.08.2013).

Strzeszewski M. (2003), Motywy poparcia lub odrzucenia integracji, CBOS Komunikat z badań, Warszawa.

Szymanik G. (2012), Włochy nie chca meczetu. „Trzeba zatrzymać tę budowę”, http://wyborcza.pl/1,126565,12373400,Wlochy_nie_chca_meczetu (dostęp: 28.08.2013). 
Ustalenia z dnia 11 stycznia 2013 roku zawarte pomiędzy Ministrem Rolnictwa i Rozwoju Wsi, Prezesem Agencji Nieruchomości Rolnych a Międzyzwiazkowym Komitetem Protestacyjnym Rolników Województwa Zachodniopomorskiego, http://www.minrol.gov.pl/pol/Ministerstwo/Biuro-Prasowe/Informacje-Prasowe/Ustalenia-w-sprawie-slupow-podpisane (dostęp: 17.09.2013).

Ustawa z dnia 6 czerwca 1997 roku Kodeks Karny, Dz. U. 1997, Nr 88, poz. 553 z późniejszymi zmianami.

Ustawa z dnia 13 czerwca 2003 roku o cudzoziemcach, Dz. U. 2011, Nr 264, poz. 1573 z późniejszymi zmianami.

Ustawa z dnia 20 kwietnia 2004 roku o promocji zatrudnienia i instytucjach rynku pracy, Dz. U. 2013, poz. 674.

Ustawa z dnia 15 czerwca 2012 roku o skutkach powierzenia wykonywania pracy cudzoziemcom przebywajacym wbrew przepisom na terytorium Rzeczypospolitej Polskiej, Dz. U. 2012, poz. 769.

Wenzel M. (2004), Obcokrajowcy w Polsce, CBOS Komunikat z badań, Warszawa.

Wenzel M. (2005), Opinie ludności z krajów Europy Środkowej i imigrantach i uchodźcach, CBOS Komunikat z badań, Warszawa.

Wenzel M. (2009), Stosunek do obcokrajowców w Polsce, Badania, Ekspertyzy, Rekomendacja Instytut Spraw Publicznych, Warszawa.

Wojdalski J. (2013), Meczet we Włochach - decyzja odmowna, „Informator Ochoty i Włoch”, nr 7, 26.04-9.05.2013.

Wybieralski M. (2009), Awantura o minaret w Poznaniu, http://wyborcza.pl/1,76842,6772198,Awantura_o_minaret_w_Poznaniu.html (dostęp: 28.08.2013).

Zapobieganie handlowi ludźmi w Polsce. Materiaty do raportu za lata 2009-2011 (2012), MSW, Warszawa.

Żbikowska I. (2013), Rasizm kwitnie na opolskich murach, http://opole.gazeta.pl/opole/1,35114, 14473758,Rasizm_kwitnie_na_opolskich_murach.html\#TRrelSST (dostęp: 28.08.2013).

\section{STRESZCZENIE}

Przedmiotem niniejszego artykułu są rozważania na temat wpływu procesów migracyjnych do Polski na poziom bezpieczeństwa społeczno-politycznego państwa i jego obywateli. Problem, który od początku lat 90 . XX wieku budził wiele emocji, ponieważ dla części polskiego społeczeństwa obecność imigrantów wywoływała niepokój, a w opinii innych była pożądana. Dokonano analizy napływu cudzoziemców do Polski na pobyt stały z podziałem na ich pochodzenie oraz rozmiarów przepływu imigrantów przez polskie granice. Odniesiono się także do konkretnych przykładów demonstracji niezadowolenia Polaków z powodu obecności obcokrajowców. Odwołano się do niekorzystnych zjawisk, które w opinii Polaków pojawiły się wraz z napływem imigrantów i mogły nadwyrężyć poziom bezpieczeństwa. Do nich zaliczono: wzrost przestępczości, nielegalnej imigracji, nielegalnego zatrudnienia i wykup polskiej ziemi. Analiza tych czterech zagadnień miała na celu zbadanie czy rzeczywiście są one realnym zagrożeniem.

\section{INTERNATIONAL MIGRATIONS TO POLAND AND SOCIO-POLITICAL SECURITY}

\section{ABSTRACT}

The subject of this article is a reflection on the impact of Polish migration processes on the level of socio-political security of the state and its citizens. This problem aroused much excite- 
ment since the early 90s of the twentieth century, because for some part of Polish society, the presence of immigrants caused public concern, in the opinion of others, it was desirable. In the article there is a brief analysis of the influx of foreigners to Poland for permanent residency with the division of their origin and the size of the flow of immigrants across Polish borders. There is also a reference to concrete examples of demonstration of dissatisfaction of Polish people due to the presence of foreigners. Subsequently in this article, it is referred to the adverse phenomena which, in the opinion of Poles, emerged with the influx of immigrants and could put a strain on the security level. These include: an increase in crime, illegal immigration, illegal employment and buying out Polish grounds. The analysis of these four issues was to assess whether they are indeed a real threat. 
